\title{
INVESTIGATION OF WATER ABSORPTION FOR CONCRETE USING SUPPLEMENTARY MATERIALS
}

\author{
Ghewa Gabriel | Priyo Surpobo* I Djoko Irawan I Sutrisno Wahyuniarsih I Tambusay Asdam
}

\footnotetext{
${ }^{1}$ Dept. of Civil Engineering, Institut Teknologi Sepuluh Nopember, Surabaya, Indonesia
}

\section{Correspondence}

*Priyo Suprobo, Dept of Civil Engineering, Institut Teknologi Sepuluh Nopember, Surabaya, Indonesia. Email:

priyo@cs.ts.ac.id

\section{Present Address}

Gedung Teknik Sipil, Jl. Taman Alumni, Surabaya 60111, Indonesia

\begin{abstract}
Concrete's durability is the key factor that affects the service life of the concrete structure. One factor that affects the durability properties of concrete is its pore structure, which can be investigated by analyzing the materials' absorption rate. For the structures with direct contact with water, water absorption can change the pore structure's behavior, affecting the durability of the conc in the long term rate. It is important to research to find the water absorption properties of concrete with different mixtures. This research investigates the rate of absorption of concrete by using fly ash and silica fume. Based on secondary absorption properties, the result shows that $15 \%$ fly ash in normal concrete increases the resistance to water penetration by $23 \%$. The usage of $5 \%$ Silica Fume increases the resistance by $11.8 \%$. The usage of $5 \%$ silica fume + $10 \%$ fly ash increases the resistance by $16.2 \%$. It shows that the use of supplementary materials in concrete increases the resistance of water penetration. In this research, the usage of $15 \%$ fly ash as cement replacement shows the best result.
\end{abstract}

\section{KEYWORDS:}

Absorption, Concrete, Durability, Materials, Structure, Sorptivity

\section{1 | INTRODUCTION}

The durability of concrete plays a critical role in controlling its serviceability. Buildings that directly contact water, such as marine infrastructure, should be resistant to water penetration, so the concrete's reinforcements did not experience corrosion. Corrosion is an electrochemical process affected by the availability of water and oxygen. Therefore, it is generally accepted that concrete durability, which is often associated with corrosion, is affected by concrete pore structure. Moreover, the concrete's pore structure mainly depends on a fluid's capacity to penetrate the concrete's microstructure, which was called permeability 1 . High permeability led to the introduction of molecules that react and destroy its chemical stability 2 .

Furthermore, the low permeability of concrete can improve resistance to water penetration, sulfate ions, chloride ions, alkali ions, and other harmful substances that caused chemical attacks ${ }^{3}$. Therefore, it is necessary to assess the rate of fluid entrance 
TABLE 1 Chemical composition of OPC.

\begin{tabular}{lr}
\hline Compound & Concentrate \\
\hline $\mathrm{Al}_{2} \mathrm{O}_{3}$ & 2.3 \\
$\mathrm{SiO}_{2}$ & 10.9 \\
$\mathrm{SO}_{3}$ & 2.48 \\
$\mathrm{~K}_{2} \mathrm{O}$ & 0.45 \\
$\mathrm{CaO}$ & 78.34 \\
$\mathrm{TiO}_{2}$ & 0.44 \\
$\mathrm{~V}_{2} \mathrm{O}_{5}$ & 0.02 \\
$\mathrm{MnO}$ & 0.072 \\
$\mathrm{Fe} \mathrm{O}_{2} \mathrm{O}_{3}$ & 4.77 \\
$\mathrm{CuO}$ & 0.076 \\
$\mathrm{ZnO}$ & 0.026 \\
$\mathrm{SrO}$ & 0.054 \\
$\mathrm{ZrO}$ & 0.028 \\
$\mathrm{BaO}$ & 0.1 \\
\hline
\end{tabular}

TABLE 2 Chemical composition of silica fume.

\begin{tabular}{lr}
\hline Compound & Concentrate \\
\hline $\mathrm{As}_{2} \mathrm{O3}$ & 0.023 \\
$\mathrm{SiO}_{2}$ & 91.1 \\
$\mathrm{SO}_{3}$ & 1.3 \\
$\mathrm{~K}_{2} \mathrm{O}$ & 3.28 \\
$\mathrm{CaO}$ & 2.3 \\
$\mathrm{TiO}_{2}$ & 0 \\
$\mathrm{VO}_{2} \mathrm{O}_{5}$ & 0 \\
$\mathrm{MnO}$ & 0.22 \\
$\mathrm{Fe} \mathrm{O}_{2}$ & 1.37 \\
$\mathrm{CuO}$ & 0.11 \\
$\mathrm{ZnO}$ & 0.154 \\
$\mathrm{SrO}$ & 0.026 \\
$\mathrm{PbO}$ & 0.054 \\
$\mathrm{BaO}$ & 0 \\
\hline
\end{tabular}

into the concrete. One test that can be used to determine the permeability properties of concrete is the rate of absorption or known as sorptivity. Sorptivity is one of the parameters which describe the durability performance of concrete. Sorptivity is a measure of the capacity of concrete to absorb water under capillary forces. Sorptivity is a rapid and straightforward test that can show the indication of transport over the concrete. Many methods are being tested and are often considered a constant value for a given concrete, thus its material feature 4 .

Other factors that can affect concrete's sorptivity values are the concrete's components, such as the cement paste matrix and its physical arrangement ${ }^{[4]}$. Sorptivity measurements are useful in determining the quantities of water absorbed. However, they yield no information on the advancing waterfront's shape or water penetration depth [5].

As well known, concrete properties, including the mechanical and durability properties, are significantly affected by its constitutive materials. Different materials used for concrete can affect its properties and behavior. In this study, besides a normal concrete, supplementary cementitious material was also used to substitute the concrete's cement content.

Supplementary Cementitious Materials (SCM) are generally incorporated as a replacement to cement to enhance the concrete characteristic. Binary blends are widely used in practice, where cement is partially replaced by supplementary cementitious materials ${ }^{6}$. Silica fume and fly ash, which have similar cement characteristics, were used in this research as supplementary material to concrete or substitute material for cement. Fly ash and silica fume have been widely used and proven to increase the mechanical performance of concrete. Moreover, this material is known as waste material, so incorporating this material into the concrete can decrease cement use, making the concrete more eco-friendly. Fly Ash, the a-by product from thermal power stations, has successfully replaced Portland cement up to $30 \%$ by mass. However, the benefit of this combination for fly ash and silica fume is not well understood 7 .

Previous research by Nagrockienè and Rutkauskas ${ }^{[8]}$ shows that using $65 \%$ fly ash as cement replacement increase the durability properties. Madani et al. ${ }^{[9}$ found that utilizing at least $3 \%$ silica fume is recommended to provide excellent performance in enhancing durability and mechanical characteristics. Based on the above facts, this research is focused on investigating the rate of water absorption on concrete using supplementary materials. This research uses ordinary concrete to compare specimen and concrete with $15 \%$ fly ash, $5 \%$ silica fume, and concrete with a combination of $10 \%$ fly ash and $5 \%$ silica fume.

\section{2 | MATERIAL AND METHOD}

\section{1 | Material}

The sample used in this research is a concrete cylinder with a diameter of $100 \times 200 \mathrm{~mm}$. The materials used in this research are normal concrete which is made with ordinary portland cement, silica fume, and fly ash, with Console SS-8 as High Range Water Reducer (HRWR). The typical chemical composition of ordinary portland cement powder, silica fume, and fly ash is given in Tables 1,2 , and 3 . 
TABLE 3 Chemical composition of fly ash.

\begin{tabular}{lrlr}
\hline Compound & Concentrate & Compound & Concentrate \\
\hline $\mathrm{Al}_{2} \mathrm{O}_{3}$ & 12.700 & $\mathrm{SiO}_{2}$ & 43.2 \\
$\mathrm{P}_{2} \mathrm{O}_{5}$ & 0.780 & $\mathrm{~K}_{2} \mathrm{O}$ & 2.37 \\
$\mathrm{CaO}$ & 9.320 & $\mathrm{TiO}$ & 1.44 \\
$\mathrm{~V}_{2} \mathrm{O}_{5}$ & 0.079 & $\mathrm{MnO}$ & 0.16 \\
$\mathrm{Fe}_{2} \mathrm{O}_{3}$ & 26.600 & $\mathrm{CuO}$ & 0.04 \\
$\mathrm{Cr}_{2} \mathrm{O}_{3}$ & 0.040 & $\mathrm{MoO}$ & 3.01 \\
$\mathrm{PbO}_{2}$ & 0.054 & $\mathrm{BaO}$ & 0.20 \\
\hline
\end{tabular}

TABLE 4 Mixed proportions.

\begin{tabular}{|c|c|c|}
\hline Type & Component & $\operatorname{Mix}\left(\mathrm{kg} / \mathrm{m}^{3}\right)$ \\
\hline \multirow[t]{5}{*}{ Normal } & Cement & 580 \\
\hline & Fine Aggregate & 680 \\
\hline & Coarse Aggregate & 1110 \\
\hline & Water & 147 \\
\hline & Console SS-8 & 800 ( $\mathrm{ml} / 100 \mathrm{Kg}$ Binder) \\
\hline Fly Ash & Cement & 493 \\
\hline \multirow[t]{5}{*}{ Concrete } & FA & 87 \\
\hline & Fine Aggregate & 680 \\
\hline & Coarse Aggregate & 1110 \\
\hline & Water & 147 \\
\hline & Console SS-8 & 800 ( $\mathrm{ml} / 100 \mathrm{Kg}$ Binder $)$ \\
\hline Silica Fume & Cement & 551 \\
\hline \multirow[t]{5}{*}{ Concrete } & SF & 29 \\
\hline & Fine Aggregate & 680 \\
\hline & Coarse Aggregate & 1110 \\
\hline & Water & 147 \\
\hline & Console SS-8 & 800 ( $\mathrm{ml} / 100 \mathrm{Kg}$ Binder) \\
\hline \multirow[t]{7}{*}{$\mathrm{FA}+\mathrm{SF}$ Concrete } & Cement & 493 \\
\hline & SF & 29 \\
\hline & FA & 58 \\
\hline & Fine Aggregate & 680 \\
\hline & Coarse Aggregate & 1110 \\
\hline & Water & 147 \\
\hline & Console SS-8 & 800 (ml/100 Kg Binder) \\
\hline
\end{tabular}

From the chemical composition above, fly ash used in this research is classified as F Class. The Mix proportions in this research are given in Table 4.

\section{2 | Method}

The experimental test in this research was performed according to using ASTM C $1585^{[10}$ as a test method. The total number of samples used in this test are five concrete cylinders with $10 \mathrm{~cm}$ diameter and $20 \mathrm{~cm}$ height). There are three types of samples used in this test. There is Normal Concrete (N), Fly Ash Concrete (FA), Silica Fume Concrete (SF), Silica Fume-Fly Ash Concrete (SA), and ECC Concrete. After being cured for 28 days, concrete samples were taken out and sliced into three identical parts (Figure 1 and Figure 2) and then placed in the oven for one day. This procedure should be performed because the samples need to be in Saturated Surface Dry (SSD) condition. Then, measure each sample weight and then wrapped each sample with plastic (Figure 3), except for the bottom side, and then it weighed in again. Each kind of concrete will be placed inside a shelter. After that, the shelter will be filled with water after it reaches about $2 \mathrm{~cm}$ from each sample's bottom surface.

The sample was weighed in after 1, 5, 10, 20,30,60,120,180, 240, 300, 360 minutes for initial absorption properties, and then it weighed in once each day until seven days for secondary absorption properties. The initial absorption properties were calculated using the Eq. 1, where points measred up to 6 hours are used.

$$
I=S i \sqrt{t+b}
$$




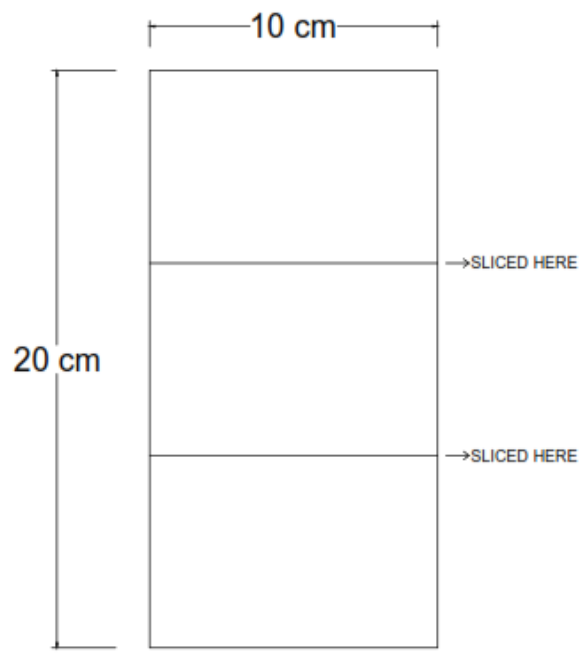

FIGURE 1 The geometry sample.

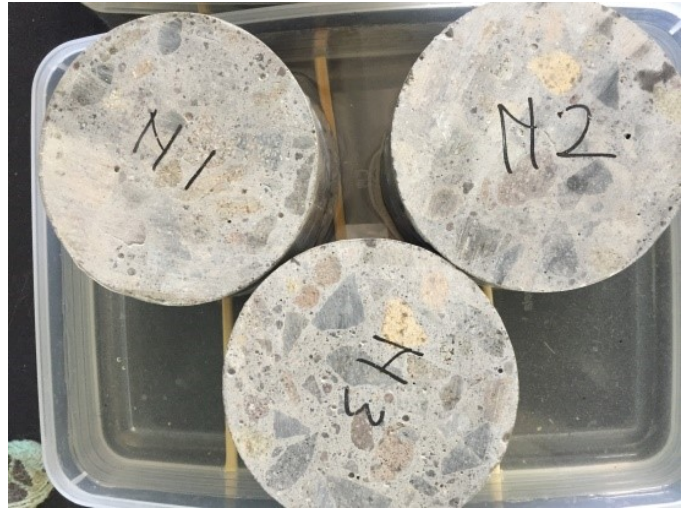

FIGURE 2 The sliced sample.

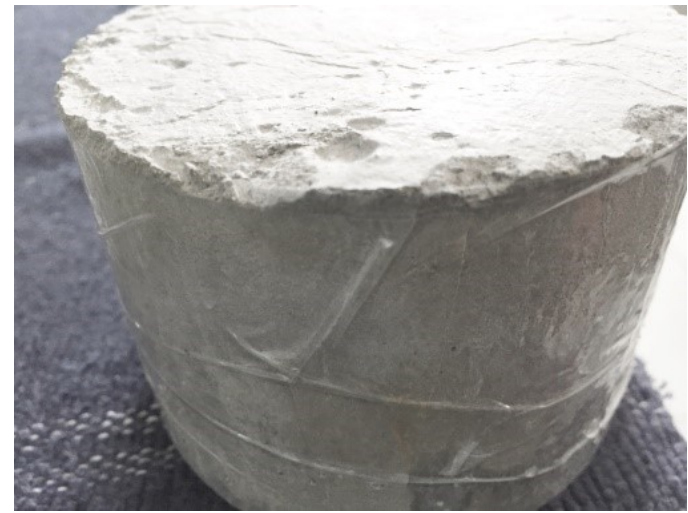

FIGURE 3 The sample of wrapped with plastic.

The secondary absorption properties were calculated using Eq. 2, points measured after the first day are used.

$$
I=S s \sqrt{t+b}
$$

For further information on water absorption properties, it needs to know each kind of concrete's sorptivity. The Sorptivity test measures the rate of absorption into the concrete pores by capillary suction. To calculate the sorptivity coefficient (S), the cumulative amount of water absorbed per cross-sectional area (i) was plotted against the square root of time $(\sqrt{t})$.

\section{3 | RESULTS AND DISCUSSION}

\section{1 | Compressive Strength of Concrete}

The specimen for this test is a cylinder with $10 \mathrm{~cm}$ diameter and $20 \mathrm{~cm}$ height. There are three samples for each kind of concrete. Table 5 and Figure 4. represent the result of this test.

As can be seen, the use of supplementary material increases the compressive strength of concrete. There is an increase of $11 \%$ in compressive strength development of concrete with $15 \%$ fly ash, an increase of $6.4 \%$ of compressive strength of concrete with $5 \%$ silica fume, and an increase of $7.3 \%$ in compressive strength of concrete with $10 \%$ fly ash and $5 \%$ silica fume. This result has 


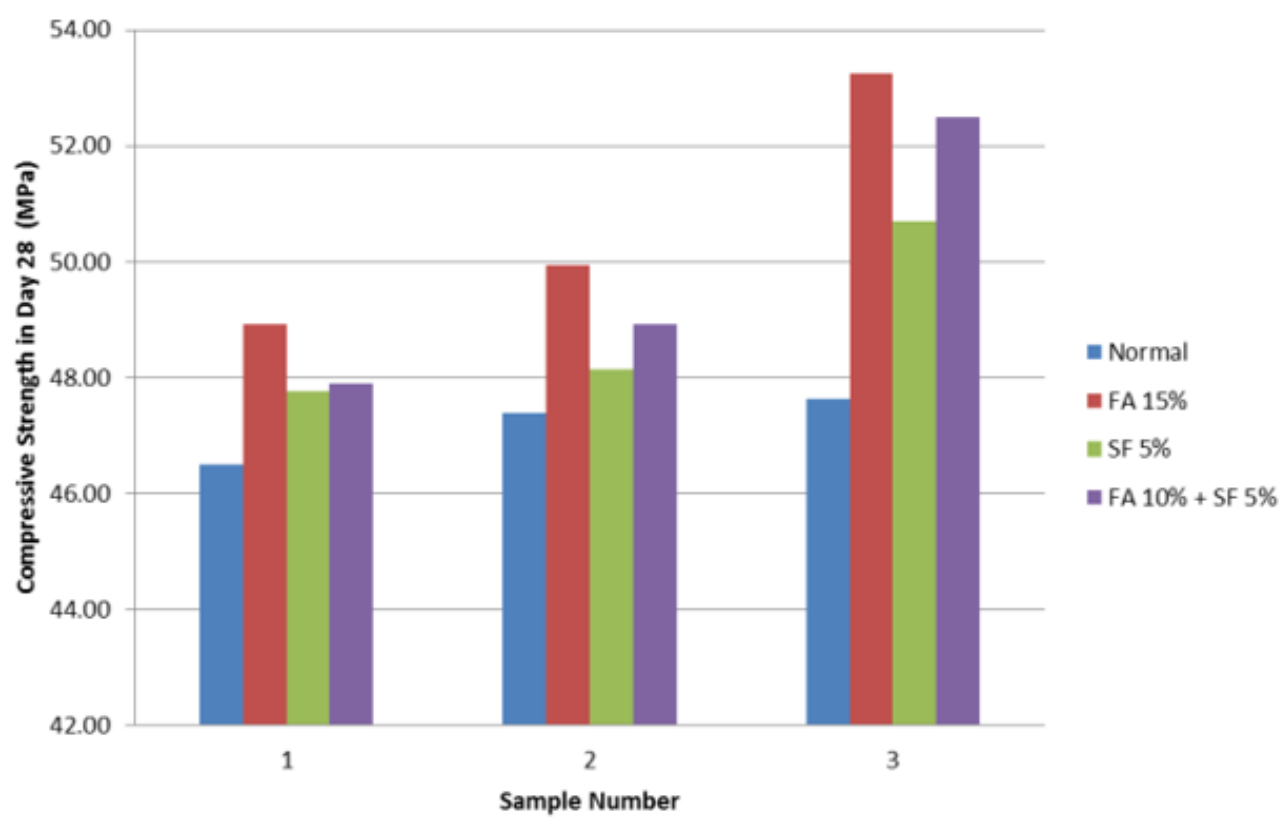

FIGURE 4 The compressing strength result.

TABLE 5 The result of concrete compressing strength measurement.

\begin{tabular}{clcc}
\hline Age (days) & Type & Force (Kgf) & Force (Fc' (Mpa) \\
\hline 28 & Normal & 36500 & 46.50 \\
& & 37200 & 47.39 \\
28 & \multirow{2}{*}{$15 \%$ FA } & 37400 & 47.64 \\
& & 38400 & 48.92 \\
\multirow{2}{*}{28} & \multirow{2}{*}{$5 \% \mathrm{SF}$} & 39200 & 49.94 \\
& & 41800 & 53.25 \\
& & 37500 & 47.77 \\
28 & \multirow{2}{*}{$10 \% \mathrm{FA}+5 \% \mathrm{SF}$} & 37800 & 48.15 \\
& & 39800 & 50.70 \\
& & 37600 & 47.90 \\
& & 38400 & 48.92 \\
\end{tabular}

a good agreement with D. Hatungimana's (2019) conclusion that the use of fly ash and silica fume increases the compressive strength of concrete. For concrete with a combination of $10 \%$ fly ash and 5\% silica fume, it has better compressive strength than concrete with a $5 \%$ silica fume. This result has a similar trend with Leung et al. ${ }^{[11]}$. He wrote that it is generally accepted that the compressive strength of concrete increases with SF and FA, especially in binary mixes with OPC. During the cement hydration process, if the excess calcium hydroxide produced reacts with just enough pozzolans to form calcium silicate hydrate (CSH), this minimum amount of pozzolans is deemed to be an optimum. The calcium hydroxide formed the interfacial transition zone around aggregates reduces the bond strength between aggregate and cement paste. Therefore, eliminating calcium hydroxide by forming additional CSH increases the binder amount and thus enhanced compressive strength ${ }^{[12}$.

\section{2 | Rate of Water Absorption}

For determining the rate of water absorption of concrete, there are two phases of this test. First. Initial absorption. Initial absorption was used to evaluate concrete's ability to resist water infiltration for the first six hours of the test. And secondary absorption was meant to evaluate concrete's ability to resist water infiltration for the next seven days. The initial absorption and secondary absorption rate are meant to evaluate the concrete sorptivity. Sorptivity value in concrete shows the ability of concrete to resist water penetration to going in its body. The sorptivity value for each kind of concrete can be seen in Figure 5 . 


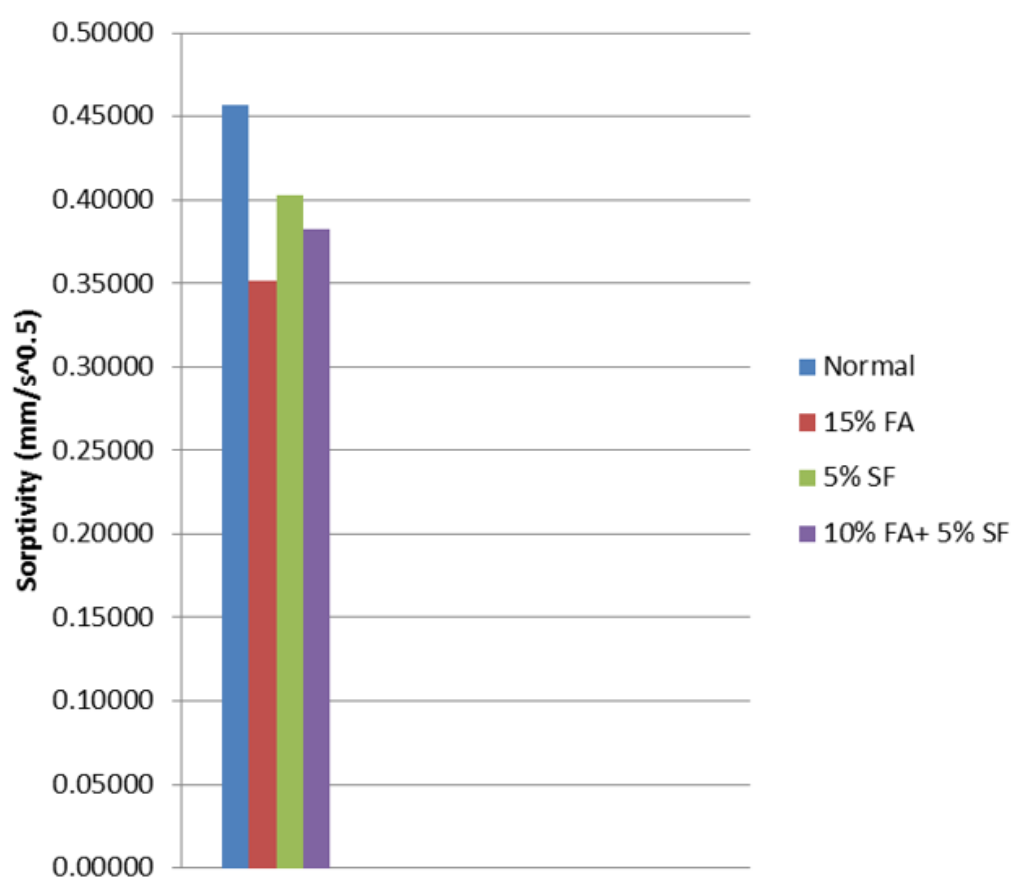

FIGURE 5 The sorptivity of concrete.

As shown in Figure 5, the addition of fly ash and silica fume decreased the concrete's water sorptivity values. As was expected, the use of supplementary material reduces the sorptivity of concrete. The low sorptivity value is because silica fume and fly ash have smaller particles than cement. It is about a thousand times smaller, making concrete has less pore, which leads to low sorptivity, so the water infiltration is not as many as the normal concrete has 12.14 .

The additional mass because of water absorption by concrete is shown in Figure 6 and Table 6 . The absorption process begins when the specimen makes contact with water. As can be seen, the usage of silica fume and fly ash in concrete reduces concrete's water absorption capacity. This result has a good agreement with Barbhuiya (2016) in his research, which has a conclusion that the introduction of silica fume reduces the water absorption capacity for concrete ${ }^{[15]}$.

As shown above, when the sample makes contact with water in a matter of minutes, it will have additional mass because of water penetration. But the penetration rate for supplementary material is a bit different for each other samples.

If supplementary materials concrete compares with normal concrete, the supplementary penetration rate is lower than normal. In the first 20 minutes, the concrete's additional mass with 10\% fly ash and 5But when it reaches 60 minutes of the test, the fly ash concrete additional mass is similar to concrete with $10 \%$ fly ash and 5\% silica fume. It seems that the fly ash concrete surface has more pore than inside, and the fly ash-silica fume concrete has a lees pore in surface but more pores inside so that when the water reaches inside the fly ash silica fume concrete, the water penetration become faster than fly ash concrete. For the initial absorption or the absorption rate under the first 6 hours, it can be seen that fly ash concrete has the lowest sorptivity. For the secondary absorption or the absorption rate from 6 hours until seven days, the result is the same as the initial absorption. Concrete using $15 \%$ fly ash in this research has the lowest sorptivity. As can be seen, all specimen meet their peak of additional mass on day 6th. It seems that on day 6th, inside the concrete body has reach saturated condition, so the water can't penetrate anymore, or the penetration rate become so slow, so it needs more than one day to fill the concrete body. For initial and secondary absorption rates can be seen in Table 7 .

Hatungimana et al. ${ }^{[12]}$ found that the mortar mixtures' water absorption values substituted with silica fume decreased as the amount of silica fume replacement increased. This may be due to the pozzolanic and micro filler effect. The water absorption values of fly ash mortar mixtures increased as the amount of fly ash replacement increased, possibly because the 28-day curing is not sufficient for the pozzolanic reaction. ${ }^{[12]}$. 


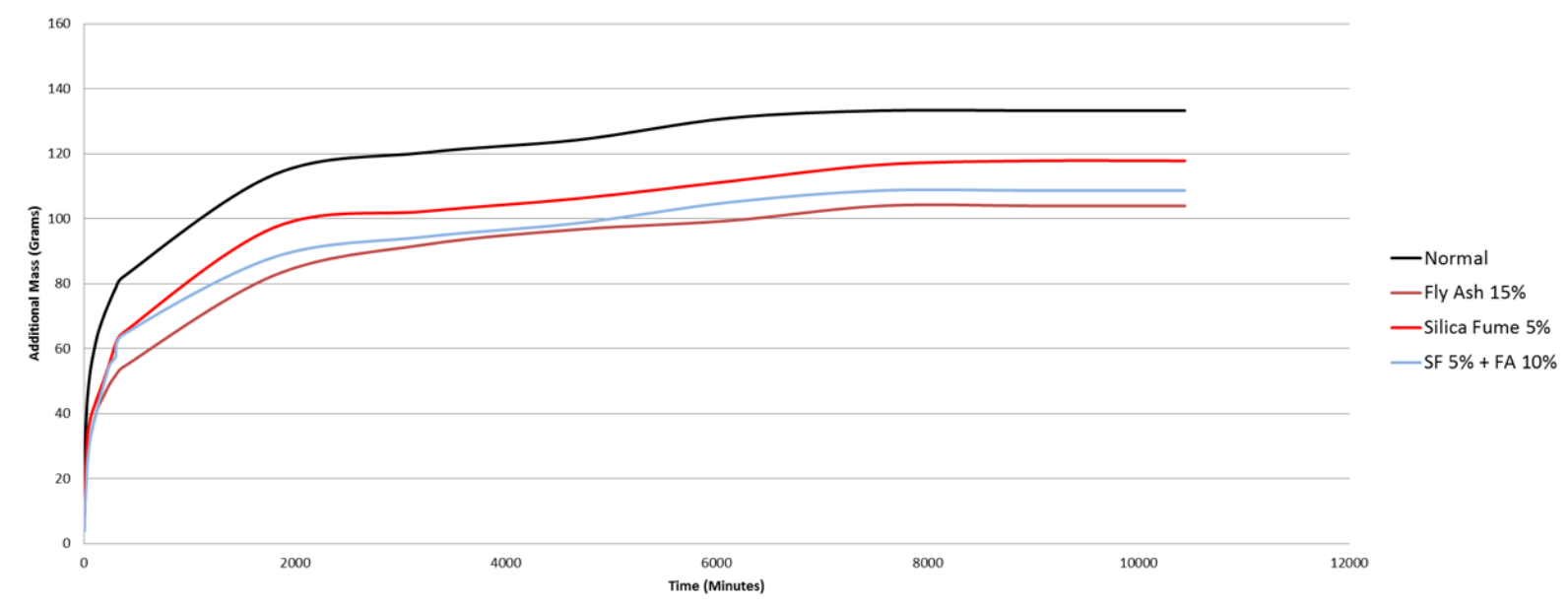

FIGURE 6 The fluctuation of concrete's mass.

TABLE 6 Concrete additional mass.

\begin{tabular}{rrrrr}
\hline \multicolumn{1}{c}{ Time } \\
(minutes) & Normal & Additional Mess (grams) & \\
$\mathbf{1 5 \%}$ FAl & $\mathbf{5 \%}$ SF & $\mathbf{1 0 \%} \mathbf{~ F A + ~ 5 \% ~ S F ~}$ \\
\hline 1 & 13.29 & 8.01 & 6.9 & 3.87 \\
15 & 25.44 & 14.82 & 14.2 & 8.82 \\
20 & 32.23 & 19.34 & 22.5 & 13.61 \\
30 & 39.8 & 23.91 & 28.3 & 19.19 \\
60 & 45 & 27.33 & 33.3 & 24.95 \\
120 & 53.88 & 33.24 & 38.9 & 33.22 \\
180 & 63.52 & 41.09 & 44.7 & 41.24 \\
240 & 69.66 & 45.22 & 49.9 & 48.5 \\
300 & 74.49 & 49.09 & 55.6 & 54.89 \\
360 & 78.8 & 51.92 & 61.7 & 57.8 \\
1800 & 81.9 & 54.17 & 64.7 & 64.12 \\
3240 & 113.59 & 82.58 & 97.3 & 88.19 \\
4680 & 120.38 & 92.06 & 102.3 & 94.46 \\
6120 & 124.24 & 96.69 & 106.2 & 98.64 \\
7560 & 130.95 & 99.4 & 111.5 & 105.04 \\
9000 & 133.24 & 103.96 & 116.6 & 108.68 \\
10440 & 133.24 & 103.96 & 117.8 & 108.68 \\
& 133.24 & 103.96 & 117.8 & 108.68 \\
\hline
\end{tabular}

In his research, the optimum fly ash replacement for cement is around $10 \%$ to $20 \%$. Leung et al. ${ }^{[11]}$ has found that when the percentage replacement of ordinary portland cement by fly ash increases from $0 \%$ to $50 \%$, the reduction in water absorbed becomes more significant. It also indicated that the addition of fly ash slightly reduces the water absorption at the initial stage.

This reduction develops with time. It meets the fact that fly ash particles fill up the micro air voids inside the concrete matrix and thus inhibit water absorption. However, when the percentage replacement of ordinary portland cement by fly ash + silica fume is greater than $35 \%$, water absorption reduction appears insignificant 111 . It is because that silica fume and fly ash cannot bind other materials better than cement. So that if the supplementary materials had been added too much, the result would be insignificant.

Based on the research before, this research result meets the same trend as other research. Supplementary concrete has better resistance to water penetration and meets the fact that concrete compressive strength with fly ash or silica fume replacement for cement is better than normal concrete.

\section{3 | Relation between Compressive Strength and Rate of Water Absorption}

In Table 5, it can be seen that concrete with 15\% fly ash as cement replacement has the highest compressive strength, followed by concrete with $10 \%$ fly ash $+5 \%$ of silica fume as a cement replacement, then concrete with $5 \%$ silica fume as a cement 
replacement, and then normal concrete. Figure 6 shows that concrete with $15 \%$ fly ash as cement replacement has the lowest sorptivity, followed by concrete with $10 \%$ fly ash $+5 \%$ silica fume, then followed by concrete with $10 \%$ fly ash $+5 \%$ of silica fume as a cement replacement, then concrete with 5\% silica fume as a cement replacement, and then normal concrete.

In Table 6, if the lowest additional mass arranges the result to the highest additional mass, the list will be the same as compressive strength and sorptivity value. From this result, it can be seen that the highest compressive strength has the lowest sorptivity value and has good resistance to water penetration. When the concrete has low compressive strength, it indicated more pores inside the concrete, becoming weaker. With fly ash and silica fume as a cement replacement, where fly ash and silica fumes particles are smaller than cement ${ }^{16}$, it is easier to fill the air void inside the concrete body, and it makes the concrete become solid and has a higher compressive strength. In this research, the mixing properties had only one mix of properties for each kind of concrete. For each supplementary concrete mix property with fly ash and silica fume as a cement replacement, it can be considered the optimum value of supplementary materials as cement replacement in this research. But supplementary materials like fly ash and silica fume must have an optimum value. If used too much as a cement replacement, the concrete will become weaker, and the concrete sorptivity becomes insignificant ${ }^{[11]}$.

\section{4 | CONCLUSION}

An investigation of water absorption for concrete using supplementary materials has been carried out. Based on the test result, there are five conclusions that can be drawn. First, in this case, supplementary materials, fly ash, and silica fume greatly impact the compressive strength test and water absorption test. Second, the optimum compressive strength was achieved by concrete with $15 \%$ fly ash as cement replacement. Third, the optimum sorptivity value was achieved by concrete with $15 \%$ fly ash as cement replacement. Fourth, when both fly ash and silica fume are adopted as a cement replacement, the sorptivity and compressive strength are better than just using silica fume. Finally, the water penetration becomes saturated on day 6th for every sample.

When supplementary materials need to use for strengthening concrete, it needs to look for the optimum value first. Otherwise, the concrete durability will not be the same as expected. The optimum value of mixed properties for concrete in this research may differ from others, but it has the same trend result. The chemical composition in this research's supplementary material is not always the same as other research.

\section{References}

1. Zhang SP, Zong L. Evaluation of relationship between water absorption and durability of concrete materials. Advances in Materials Science and Engineering 2014;2014:1-9.

2. Monteiro P, Mehta P. Concrete: Microstructure, Properties and Materials. McGraw-Hill; 2006.

3. Alhozaimy A, Soroushian P, Mirza F. Effects of curing conditions and age on chloride permeability of fly ash mortar. ACI Materials Journal 1996;93(1):87-95.

4. Kubissa W, Jaskulski R, Koteš P, Brodňan M. Variability of Sorptivity in the Concrete Element According to the Method of Compacting. Procedia Engineering 2016;153:355-360.

5. McCarter WJ, Ezirim H, Emerson M. Absorption of water and chloride into concrete. Magazine of Concrete Research 1992;44(158):31-37.

6. Zhong R, Wille K. Material design and characterization of high performance pervious concrete. Construction and Building Materials 2015 nov;98:51-60.

7. Barbhuiya SA, Gbagbo JK, Russell MI, Basheer PAM. Properties of fly ash concrete modified with hydrated lime and silica fume. Construction and Building Materials 2009;23(10):3233-3239.

8. Nagrockienè D, Rutkauskas A. The effect of fly ash additive on the resistance of concrete to alkali silica reaction. Construction and Building Materials 2019;201. 
9. Madani H, Norouzifar MN, Rostami J. The synergistic effect of pumice and silica fume on the durability and mechanical characteristics of eco-friendly concrete. Construction and Building Materials 2018 jun;174:356-368.

10. ASTM C1585-13. Standard Test Method for Measurement of Rate of Absorption of Water by Hydraulic Cement Concretes. ASTM International 2013;41(147):1-6.

11. Leung HY, Kim J, Nadeem A, Jaganathan J, Anwar MP. Sorptivity of self-compacting concrete containing fly ash and silica fume. Construction and Building Materials 2016 jun;113:369-375.

12. Hatungimana D, Taşköprü C, İçhedef M, Saç MM, Yazıcı S. Compressive strength, water absorption, water sorptivity and surface radon exhalation rate of silica fume and fly ash based mortar. Journal of Building Engineering 2019 may;23:369376.

13. Chen X, Wu S, Zhou J. Influence of porosity on compressive and tensile strength of cement mortar. Construction and Building Materials 2013 mar;40:869-874.

14. Erniati, Tjaronge MW, Zulharnah, Irfan UR. Porosity, pore size and compressive strength of self compacting concrete using sea water. In: Procedia Engineering, vol. 125 Elsevier Ltd; 2015. p. 832-837.

15. Amudhavalli NK, Mathew J. Effects of Silica Fume on the Strength and Durability Parameters of Concrete. International Journal of Engineering Sciences \& Emerging Technologies 2012;3(1):28-35.

16. Zhang Z, Yuvaraj A, Di J, Qian S. Matrix design of light weight, high strength, high ductility ECC. Construction and Building Materials 2019 jun;210:188-197.

How to cite this article: Gabriel G., Priyo S., Djoko I., Wahyuniarsih S., Asdam T., (2020), Investigation of Water Absorption for Concrete Using Supplementary Materials, IPTEK The Journal of Technology and Science, 31(3):309-317. 